\title{
New era of Genes and Environment
}

\author{
Yasunobu Aoki
}

\begin{abstract}
Genes and Environment is now at the start of a new era of publication as an open access journal. I believe that open access publication marks a turning point that will make Genes and Environment unique in the Asian environmental mutagen research community.
\end{abstract}

Keywords: Environmental agent, Genotoxicity, Mutagen, Mutation research, Open access Journal

In 2015 Genes and Environment is at the start of a new era of publication as an open access journal. The transformation of Genes and Environment, the official journal of the Japanese Environmental Mutagen Society (JEMS), to open access is the beginning of a great epoch for JEMS. I would like to especially thank Dr. Takashi Yagi Editor-in-Chief, for his tireless efforts in this process, which was planned in May 2014 by the Editorial Committee. After discussions among Editorial Committee members and Council members, JEMS chose BioMed Central as the journal's open access publisher. Articles in Genes and Environment are now accessible via the journal's homepage at BioMed Central, and previous content can be accessed on the JEMS homepage.

Genes and Environment has published many outstanding articles in the field of mutation research, including articles on the mechanisms by which environmental agents induce mutations. I believe that open access publication marks a turning point that will make Genes and Environment unique in the Asian environmental mutagen research community. Asian countries share issues that need to be resolved; for example, the people of Asia are concerned that diseases such as cancers may be caused by agents in environmental media such as the air or water, or in food, and this concern will be an important topic in the new Genes and Environment.

JEMS plans for growing Genes and Environment into a mainstream journal in the field of mutation research. All mutation researchers are invited to submit their latest manuscripts to Genes and Environment.

Correspondence: ybaoki@nies.go.jp

Center for Environmental Risk Research, National Institute for Environmental Studies, 16-2 Onogawa, Tsukuba, Ibaraki 305-8506, Japan

\section{Competing interests}

The author declares no competing interests.

\section{Author's information}

Yasunobu Aoki is the President of the Japanese Environmental Mutagen Society, Center for Environmental Risk Research, National Institute for Environmental Studies.

Received: 27 April 2015 Accepted: 14 May 2015

Published online: 16 June 2015

\section{Submit your next manuscript to BioMed Central and take full advantage of:}

- Convenient online submission

- Thorough peer review

- No space constraints or color figure charges

- Immediate publication on acceptance

- Inclusion in PubMed, CAS, Scopus and Google Scholar

- Research which is freely available for redistribution

Submit your manuscript at www.biomedcentral.com/submit
C Biomed Central

(c) 2015 Aoki. This is an Open Access article distributed under the terms of the Creative Commons Attribution License (http:// creativecommons.org/licenses/by/4.0), which permits unrestricted use, distribution, and reproduction in any medium, provided the original work is properly credited. The Creative Commons Public Domain Dedication waiver (http://creativecommons.org/ publicdomain/zero/1.0/) applies to the data made available in this article, unless otherwise stated. 